American Journal of Pharmaceutical Education 2019; 83 (7) Article 6988.

\title{
RESEARCH
}

\section{A Laboratory Session to Prepare Pharmacy Students to Manage the Opioid Crisis Situation}

\author{
Krista L. Donohoe, PharmD, Archana Raghavan, PharmD, Thuy T. Tran, PharmD, Fawaz M. Alotaibi, PharmD, \\ Kacie E. Powers, PharmD, Laura M. Frankart, PharmD \\ Virginia Commonwealth University School of Pharmacy, Richmond, Virginia \\ Submitted January 31, 2018; accepted June 25, 2018; published September 2019.
}

\begin{abstract}
Objective. To educate third-year pharmacy students about the role of pharmacists in the opioid crisis and measure their knowledge, confidence, and attitudes towards opioids and opioid overdose.

Methods. All third-year students $(n=130)$ enrolled in a Doctor of Pharmacy (PharmD) degree program participated in opioid overdose and naloxone education and training followed by a three-part laboratory session that included mock naloxone counseling, case-based discussion of the Prescription Drug Monitoring Program (PDMP), and equianalgesic opioid dose conversion scenarios. A pre- and postassessment focused on the individual's clinical knowledge, confidence, and attitudes about opioid overdose management and naloxone use was administered before and after the laboratory session to evaluate the student's baseline understanding and experience compared to learning gains from the session. An evaluation of the laboratory session was also conducted.

Results. Upon completion, 99\% percent of students rated the opioid laboratory as excellent (59\%) or good (40\%). Students believed the laboratory was stimulating (93\%), relevant to pharmacy practice (96\%), and contributed to their professional development (97\%), and that the information provided was at an appropriate level (98\%). Knowledge-based assessments improved in the areas of PDMP timely reporting, differentiating between naloxone devices, and naloxone administration technique. Student attitudes toward managing opioid overdoses improved on a majority of items. The majority of students agreed they had enough information to help them manage an opioid overdose (88.5\%) and denied the need for additional training (61.5\%).

Conclusion. An active-learning laboratory helped to improve pharmacy students' knowledge, confidence, and attitudes with regard to opioids and the use of naloxone to treat a patient who has overdosed.
\end{abstract}

Keywords: opioids, laboratory, active-learning, naloxone training, PDMP

\section{INTRODUCTION}

Prescription opioid misuse and abuse have become epidemic in the United States. ${ }^{1}$ According to the Centers for Disease Control and Prevention (CDC), there has been an overall increase in opioid prescriptions written over the past 15 years, despite that the amount of pain reported by Americans has not changed significantly. ${ }^{2}$ Opioid use for pain has been present in the United States for many decades. The rise in abuse of these substances, however, can be attributed to changes in prescriber attitudes toward opioids for the treatment of chronic pain, which has led to changes in prescription trends. ${ }^{3}$ Potential causes for the opioid crisis include events which led to the over pre-

Corresponding Author: Krista L. Donohoe, Virginia Commonwealth University School of Pharmacy, 410 N 12th St., Richmond, VA 23298-0533. Tel: 804-628-4551. Fax: 804828-0343. E-mail: KLDonohoe@vcu.edu scription of these medications. In the United States in the 1970s, opioids were primarily prescribed to treat acute pain related to surgery and injury or severe pain associated with cancer. Evidence to support prescribing opioids for chronic pain conditions was absent, and physicians were concerned about the addiction potential with longterm opioid use in patients as well as the associated liability for themselves. In 1980, a letter to the editor about a retrospective review published in the New England Journal of Medicine stated that only a small number of patients who were given opioids for pain became addicted. Many believe that the letter changed the management of chronic pain the United States. ${ }^{3}$ Although this publication may have been only one of many factors that precipitated the opioid epidemic, pain management organizations, physicians, and the World Health Organization used this letter to begin advocating for the use of opioids for the treatment of chronic, non-cancer-related pain. ${ }^{3}$ Pharmaceutical 


\section{American Journal of Pharmaceutical Education 2019; 83 (7) Article 6988.}

manufacturers developed new opioids with extendedrelease formulations and began aggressively marketing their opioids to primary care physicians for use in the treatment of chronic pain. In addition to this event, studies published in the 1990s demonstrating that cancer and noncancer pain were undertreated led to the 2001 announcement by the Joint Commission for a new standard for monitoring pain as the "fifth vital sign," with an emphasis on treating pain in the inpatient setting. In addition, reimbursement through the Medicare Inpatient Prospective Payment System was tied to patient satisfaction surveys, the responses to which could be affected by patients' perception of their pain control. This combination of factors led to increasing rates of opioid prescribing from 1995-2012, with corresponding increases in deaths from opioid overdose and cases of opioid addiction. ${ }^{4}$

Pharmacists are key players in helping to combat the opioid epidemic as they are the most accessible health care provider for patients. ${ }^{5}$ Pharmacists work with prescribers to help choose appropriate pain medication regimens to reduce the risk of patient addiction and overdose. Pharmacists can also educate patients regarding the adverse effects of opioids and the signs and symptoms of overdose. ${ }^{6}$ Recently, tools have been created to help pharmacists play a bigger role in combating the opioid epidemic. One example is Prescription Drug Monitoring Programs (PDMPs) that have been put in place to give pharmacists and other health care providers the ability to see a patient's controlled substance prescription history in order to aid in detecting signs of diversion and misuse. ${ }^{1}$ However, when presented with this information, many pharmacists do not know the proper actions to take when possible red flags for abuse and misuse are identified. In a survey conducted by the National Center of Addiction and Substance Abuse at Columbia University, only $62 \%$ of pharmacists felt confident in their ability to recognize drug diversion. ${ }^{1}$ Furthermore, many US pharmacy schools lack adequate education and training for students on aspects of opioid medication use. ${ }^{7}$ In the 2016-2017 final report of the AACP Bylaws and Policy Development Committee, policy statement 4 states that schools and colleges of pharmacy are strongly advised to equip their students with the knowledge necessary to educate patients, families, and caregivers of the hardships associated with pain management and the treatment and prevention of substance use disorders. ${ }^{8}$

One way to improve the knowledge of future pharmacists is by creating a series of laboratory exercises for students to help prepare them for their future careers. Virginia Commonwealth University School of Pharmacy has designed a laboratory session for their third-year pharmacy students that gives them the knowledge and tools necessary to help combat the opioid epidemic in the following ways: by detecting red flags in PDMPs, correctly dosing patients taking opioid medications, and educating and counseling caregivers on how to use naloxone in the case of an opioid overdose. The objective of this study was to teach thirdyear pharmacy students the role pharmacists play in the opioid crisis, and to measure the extent of their knowledge, confidence, and attitudes towards opioids and opioid overdose before and after completing the training.

\section{METHODS}

One hundred thirty third-year pharmacy students were enrolled in the active-learning, skills laboratory course during the 2017 fall semester. The skills laboratory is a one-credit course and the fifth in a six-semester practice-based laboratory sequence. The three laboratory sections on the main campus had from 34 to 36 students each, and the two satellite campuses in Fairfax and Charlottesville had 19 students and five students, respectively. This laboratory session was designed to be taught in parallel with the Clinical Therapeutics Neurology Module in which pain management is taught.

The laboratory session was based on the REVIVE! Opioid Overdose and Naloxone Education (OONE) program. REVIVE! is a collaborative effort supported by the Virginia Department of Behavioral Health and Developmental Services (DBHDS), Virginia Department of Health, Virginia Department of Health Professions, and recovery community organizations around Virginia. ${ }^{9}$ Similar programs are available in other states through community-based organizations, health care facilities, Veterans Administration healthcare systems, state or local health departments, and pharmacies. ${ }^{10}$ The course coordinators at the main and satellite campuses were certified over the summer to train the trainers so they could evaluate the students during the practical portion of the laboratory sessions.

Before the laboratory session, a one-hour lecture on opioid overdose and naloxone was delivered to all 130 students by one of the course coordinators. The laboratory session consisted of three parts: a small-group discussion and activity on PDMP, opioid equianalgesic case scenarios, and naloxone counseling with REVIVE! certification. The first part of the laboratory was a 20-minute small group discussion of the PDMP using a patient case example led by a faculty member. This included several audience response questions aimed at revealing preconceived attitudes about opioids and discussed the pharmacists' role in the opioid epidemic. Next, students worked on patient case vignettes using equianalgesic tables to determine how to convert from one opioid medication to another. While some of students worked individually on their case scenarios, other students participated in counseling session with a mock patient's caregiver on the naloxone injection with 


\section{American Journal of Pharmaceutical Education 2019; 83 (7) Article 6988.}

atomizer as this method of administering naloxone requires the most steps. Graduate teaching assistants, fourth-year pharmacy students on a teaching rotation, and faculty members were used to evaluate the students in these counseling sessions using a standardized rubric. Course coordinators who were certified to train the trainers had students use mannequins to demonstrate how to use naloxone to revive a patient who had overdosed on an opioid. Students working in pairs demonstrated their proficiency with using either the EVZIO auto-injector or the Narcan nasal spray. After they were deemed proficient, they received a REVIVE! certification card stating they were trained in REVIVE! procedures.

A pre-assessment that included 10 knowledge-based multiple-choice questions, five confidence questions, and an attitudes survey was administered on Blackboard immediately prior to the start of the Clinical Therapeutics Neurology Module, three weeks before the students participated in the laboratory activity. At the end of the semester, a post-assessment survey with the confidence questions, attitudes, and laboratory evaluation were administered via Blackboard during a laboratory session. Nine of the same knowledge-based questions were administered as part of the final examination in the skills laboratory course administered on Examplify (ExamSoft, Dallas, TX).

The validated Opioid Overdose Attitudes Scale (OOAS) was used after obtaining permission from the author. ${ }^{11}$ The OOAS had 28 questions and students were asked to mark each statement using the following responses: completely disagree, disagree, unsure, agree, or completely agree. Each question was categorized into three subgroups: competence, concerns, and readiness. ${ }^{12}$ Competence items assessed the individual's personal ability to manage an overdose. The concerns items assessed the individual's concerns about addressing an overdose. Readiness items gauged the individual's willingness to make an intervention if they encountered a patient who had overdosed. The OOAS results were scored continuously based on points, ranging from 1 to 5 , assigned to each response selection. The score for a negative statement, such as "I would be afraid of giving naloxone in case the person becomes aggressive afterwards," was reversed prior to computing its total points. The sum of each response was tallied to determine the cumulative score for each subcategory. The total possible score on the OOAS ranged from 28 to 140 points. The Wilcox signed rank test was used to analyze the results with a $<.05$ level of significance.

Five confidence questions were used related to the student's ability to counsel a patient regarding different naloxone formulations counsel a patient or caregiver on recognizing an opioid overdose, and their ability to perform opioid equianalgesic dosing conversions. The students rated their level of confidence using a Likert scale on which $1=$ not at all confident, $2=$ not very confident, $3=$ somewhat confident, $4=$ very confident, $5=$ completely confident.

Evaluation of the laboratory consisted of five questions which were rated using a Likert scale on which $1=$ strongly disagree, $2=$ disagree, $3=$ undecided, $4=$ agree, and $5=$ strongly agree. Finally, students were asked one question regarding the overall quality of the laboratory session, which they rated on a Likert scale on which $1=$ very poor, $2=$ poor, $3=$ fair, $4=$ good, and $5=$ excellent. The laboratory evaluation included questions about whether the laboratory was well-organized, contributed to the student's professional development, was relevant, was interesting and/or stimulating, and if the information was at an appropriate level for the student's understanding.

All students' assessments were extracted from Blackboard and Examsoft and imported into SAS version 9.4 (SAS Institute Inc, Cary, NC). Percentage was reported for all of the assessment elements. Because of the small number of responses in each question, we combined completely disagree and disagree responses, agree and completely agree responses, completely confident and very confident responses, not very confident and not at all confident responses, strongly disagree and disagree responses, and agree and strongly agree responses. Fisher exact test was performed for any question with five responses or less, which included the attitude and confidence assessments. The McNemar test was performed to determine the differences in two proportions in the knowledge questions at a $<.05$ level of significance.

Participation in the assessments was required as part of the course, however, participation in the study was voluntary. Thus, consent was obtained from students for their data to be used for research purposes. Student data were de-identified. This study was approved as exempt research by the Virginia Commonwealth University Institutional Review Board.

\section{RESULTS}

The opioid laboratory session achieved an overall favorable rating from $99 \%$ of the students $(59 \%$ rated the laboratory session as excellent and $40 \%$ rated it as good). Students also agreed that the laboratory was stimulating (93\%), the information provided was at an appropriate level (98\%), it was relevant to pharmacy practice (96\%), and it contributed to their professional development (97\%) (Table 1).

After the laboratory, a significant shift was observed in students' opinions regarding the importance 


\section{American Journal of Pharmaceutical Education 2019; 83 (7) Article 6988.}

Table 1. Pharmacy Students' Evaluation of the Opioid Overdose Management Laboratory Session (N=124)

\begin{tabular}{|c|c|c|c|c|c|}
\hline Question & $\begin{array}{c}\text { Strongly Disagree } \\
(\%)\end{array}$ & $\begin{array}{l}\text { Disagree } \\
(\%)\end{array}$ & $\begin{array}{l}\text { Undecided } \\
(\%)\end{array}$ & $\begin{array}{c}\text { Agree } \\
(\%)\end{array}$ & $\begin{array}{c}\text { Strongly Agree } \\
(\%)\end{array}$ \\
\hline $\begin{array}{l}\text { The information was at a level } \\
\text { appropriate for my understanding. }\end{array}$ & 1.6 & 0 & 0 & 33.8 & 64.5 \\
\hline $\begin{array}{l}\text { The laboratory was interesting and/or } \\
\text { stimulating. }\end{array}$ & 0.8 & 3.2 & 2.4 & 50.8 & 42.7 \\
\hline $\begin{array}{l}\text { The laboratory content is relevant to } \\
\text { pharmacy practice. }\end{array}$ & 1.6 & 0.8 & 1.6 & 29 & 66.9 \\
\hline The laboratory was well-organized. & 3.2 & 0 & 0 & 49.2 & 47.6 \\
\hline $\begin{array}{l}\text { The laboratory contributed to my } \\
\text { professional development. }\end{array}$ & 1.6 & 0 & 0.8 & 43.5 & 54 \\
\hline Laboratory Rating & Very Poor & Poor & Fair & Good & Excellent \\
\hline Overall, I would rate this laboratory as: & 0 & 0 & 1.6 & 39.5 & 58.9 \\
\hline
\end{tabular}

of pharmacists' involvement in providing opioid therapy management. In the post-assessment, there was a $13.8 \%$ increase in the number of responses, who deemed pharmacist's involvement as "very important" $(p<.001)$. About $90 \%$ of students considered a pharmacist's knowledge of naloxone to be very important both before and after the laboratory exercise (Table 2).

Students' confidence level in counseling patients on how to use various naloxone devices was assessed. A significant increase in students' confidence in counseling a patient on the use of naloxone nasal spray with or without an atomizer was $85 \%$ and $65 \%$ respectively $(p<.001)$. An $8.2 \%$ decrease (from $94.3 \%$ to $86.1 \%$ ) in the percentage of students who were confident about counseling a patient in the use of a naloxone auto-injector was observed in the post-assessment. A majority of students (75\%) expressed confidence in their ability to perform opioid equianalgesic dosing conversions and counsel a patient or caregiver about how to recognize an opioid overdose (Table 3).

In knowledge assessments, students demonstrated a good baseline understanding of naloxone's role in an opioid overdose episode and naloxone's quick onset of action, ability to recognize opioid withdrawal-related symptoms, and to perform opioid dosage conversion. Their knowledge compared to baseline improved in the following areas: timeliness of PDMP reporting, distinguishing between naloxone devices, and naloxone administration technique. Students' performance on the question pertaining to medications included in the Virginia's PDMP database was the lowest on the post-assessment (Table 4).

All students $(n=130)$ were able to proficiently demonstrate medical steps needed in an opioid overdose and were REVIVE! certified. Students scored between 9.5 and 25 points out of 25 possible points on the opioid equianalgesic cases, with a mean score of $21.4(\mathrm{SD}=3.4)$. With regards to the counseling activity for the naloxone nasal spray with atomizer, students' scores ranged from $67.5 \%$ to $100 \%$. The average score was $94.2 \%(\mathrm{SD}=5.43 \%)$.

Students' scores on the majority of the 21 items on the OOAS statistically improved from baseline (Table 5). The biggest changes were found in the following: being able to inject naloxone $(+84.3 \%)$, effectively dealing with an overdose $(+69 \%)$, having enough information to manage an overdose $(+68.9 \%)$, and knowing what to do if a patient had overdosed $(+66.9 \%)$. There was no significant change in students' responses on six of the

Table 2. Pharmacy Students' Perceptions of the Importance of Pharmacist Involvement in Opioid Management and Naloxone Education Before and After Completing an Opioid Overdose Management Laboratory Session $(\mathrm{N}=129)$

\begin{tabular}{|c|c|c|c|c|c|c|c|}
\hline Question & \multicolumn{2}{|c|}{$\begin{array}{c}\text { Very } \\
\text { Important }\end{array}$} & \multicolumn{2}{|c|}{$\begin{array}{c}\text { Neither } \\
\text { Important nor } \\
\text { Unimportant }\end{array}$} & \multicolumn{2}{|c|}{$\begin{array}{l}\text { Not Very } \\
\text { Important }\end{array}$} & $p$ value \\
\hline $\begin{array}{l}\text { In your opinion, how important is it for a pharmacist to be involved } \\
\text { with educating patients about opioid therapy management? }\end{array}$ & 72.4 & 86.2 & 27.6 & 9.8 & 0 & 4.1 & $<.001$ \\
\hline $\begin{array}{l}\text { In your opinion, how important is it for a pharmacist to be involved } \\
\text { with educating patients about naloxone use? }\end{array}$ & 89.4 & 90.2 & 4.1 & 1.6 & 6.5 & 8.1 & $<.001$ \\
\hline
\end{tabular}




\section{American Journal of Pharmaceutical Education 2019; 83 (7) Article 6988.}

Table 3. Pharmacy Students' Confidence in Opioid Overdose Management and Performing Dosing Conversions Before and After Completing an Opioid Overdose Management Laboratory Session $(\mathrm{N}=129)$

\begin{tabular}{|c|c|c|c|c|c|c|c|}
\hline \multirow[b]{2}{*}{ Question } & \multicolumn{2}{|c|}{ Confident } & \multicolumn{2}{|c|}{$\begin{array}{l}\text { Somewhat } \\
\text { Confident }\end{array}$} & \multicolumn{2}{|c|}{ Not Confident } & \multirow[b]{2}{*}{$p$ Value } \\
\hline & Pre \% & Post \% & Pre \% & Post \% & Pre \% & Post \% & \\
\hline $\begin{array}{l}\text { I am confident in my ability to counsel a patient on the use of a } \\
\text { naloxone auto-injector. }\end{array}$ & 94.3 & 86.1 & 5.7 & 9.8 & 0 & 4.1 & $<.001$ \\
\hline $\begin{array}{l}\text { I am confident in my ability to counsel a patient or caregiver } \\
\text { on how to recognize an opioid overdose. }\end{array}$ & 96.7 & 95.9 & 3.3 & 1.7 & 0 & 2.5 & $<.001$ \\
\hline $\begin{array}{l}\text { I am confident in my ability to counsel a patient on the use of a } \\
\text { naloxone nasal spray without an atomizer. }\end{array}$ & 50.4 & 65 & 26 & 10 & 24 & 25 & $<.001$ \\
\hline $\begin{array}{l}\text { I am confident in my ability to counsel a patient on the use of a } \\
\text { naloxone nasal spray with an atomizer. }\end{array}$ & 74 & 85 & 11 & 6 & 14 & 9 & $<.001$ \\
\hline $\begin{array}{l}\text { I am confident in my ability to perform opioid equianalgesic } \\
\text { dosing conversion. }\end{array}$ & 46.3 & 75 & 36.4 & 14 & 17.4 & 11 & $<.001$ \\
\hline
\end{tabular}

questions. After completing the laboratory session, there was a statistical decline in the number of students who indicated they did not want to help a patient because they would feel it was their responsibility if the patient died. At baseline, most students believed they were compelled to take action (96\%), and would attempt (93\%) and do the necessary steps $(90 \%)$ to help save a patient's life. They believed the patient and their family members should also be prepared to handle an overdose $(97 \%)$. After the laboratory activity, students' responses to these items remained consistent. Additionally, $88.5 \%$ of students agreed that after completing the laboratory session, they had enough information to help manage an overdose compared to only $19.6 \%$ who agreed with this before completing this activity. After completing the laboratory session, more than $60 \%$ of students denied the need for additional training to help them provide care for a patient who had overdosed. Also, fewer respondents believed they would panic $(4 \%)$ or make a mistake $(25 \%)$ in an overdose situation (Table 5).

In scoring the OOAS, significant differences in scores were observed for all three subcategories (Table 6). While the concerns and readiness subcategories only had a 2-point increase post-assessment, the competence subcategory had the highest increase ( +15 points). These changes resulted in an average overall 20-point increase to students' total score on the post-assessment.

\section{DISCUSSION}

Overall, the laboratory training session was received favorably by the students. Most strongly believed the pharmacist should have an integral role in addressing the opioid crisis through patient education and direct medication reversal of an overdose. From the start, students had a relatively good conceptual understanding of the individual components relevant to identifying an

Table 4. Percentage of Items Pharmacy Students' Answered Correctly on the Knowledge-Based Opioid Overdose Management Questions Before and After Completing an Opioid Overdose Management Laboratory Session $(\mathrm{N}=130)$

\section{Question}

Naloxone has a __ onset and a duration of action that may last up to

\begin{tabular}{cc}
$\begin{array}{c}\text { Pre } \\
\text { \% }\end{array}$ & $\begin{array}{c}\text { Post } \\
\%\end{array}$ \\
\hline 90 & $99^{\mathrm{a}}$ \\
17 & $68^{\mathrm{a}}$ \\
& \\
52 & $91^{\mathrm{a}}$ \\
70 & $97^{\mathrm{a}}$ \\
44 & 55 \\
& \\
39 & $85^{\mathrm{a}}$ \\
87 & 90 \\
94 & 100 \\
95 & 100 \\
\hline
\end{tabular}

When using the naloxone intranasal $0.4 \mathrm{mg} / 0.1 \mathrm{~mL}$ device, you should gently insert and press the nozzle plunger to

Which of the following statements best describes the naloxone $2 \mathrm{mg} / 2 \mathrm{~mL}$ pre-filled syringe formulation?

When administering the naloxone auto-injector, it should be injected into the

In addition to gabapentin, which medications are included in the central database of the Virginia Prescription

Monitoring Program?

Pharmacies are required to report information to the Prescription Monitoring Program (PMP) within _

Which of the following statements best describes the opioid withdrawal syndrome?

Opioid Conversion-Based Question

The purpose of naloxone administration during an opioid emergency is to reverse - associated with overdose?

${ }^{a}$ The proportion was significant at $p<.05$ 


\section{American Journal of Pharmaceutical Education 2019; 83 (7) Article 6988.}

Table 5. Pharmacy Students Responses on an Opioid Overdose Attitude Scale ${ }^{11}$ Assessment $(\mathrm{N}=129)$ Before and After Completing an Opioid Overdose Management Laboratory Session

\begin{tabular}{|c|c|c|c|c|c|c|c|}
\hline \multirow[b]{2}{*}{ Select Competence Questions } & \multicolumn{2}{|c|}{$\begin{array}{c}\text { Disagree/ } \\
\text { Completely } \\
\text { Disagree }\end{array}$} & \multicolumn{2}{|c|}{ Unsure } & \multicolumn{2}{|c|}{$\begin{array}{c}\text { Agree/ } \\
\text { Completely } \\
\text { Agree }\end{array}$} & \multirow[b]{2}{*}{$p$ Value } \\
\hline & $\begin{array}{l}\text { Pre } \\
\%\end{array}$ & $\begin{array}{c}\text { Post } \\
\%\end{array}$ & $\begin{array}{l}\text { Pre } \\
\%\end{array}$ & $\begin{array}{c}\text { Post } \\
\%\end{array}$ & $\begin{array}{c}\text { Pre } \\
\%\end{array}$ & $\begin{array}{c}\text { Post } \\
\%\end{array}$ & \\
\hline $\begin{array}{l}\text { I already have enough information about how to manage } \\
\text { an overdose }\end{array}$ & 69 & 1.6 & 11.5 & 9.8 & 19.6 & 88.5 & $<.001$ \\
\hline $\begin{array}{l}\text { I am already able to inject naloxone into someone who } \\
\text { had overdosed }^{\text {b }}\end{array}$ & 47.8 & 3.3 & 12.2 & 2.4 & 10 & 94.3 & $<.001$ \\
\hline $\begin{array}{l}\text { I would be able to check that someone who had an } \\
\text { overdose was breathing properly }\end{array}$ & 21 & 0 & 21 & 2.4 & 57.7 & 97.5 & $<.001$ \\
\hline $\begin{array}{l}\text { I am going to need more training before I would feel } \\
\text { confident to help someone who had overdosed }\end{array}$ & 9.8 & 71.3 & 4.9 & 12.3 & 85.3 & 16.4 & $<.001$ \\
\hline $\begin{array}{l}\text { I would be able to perform mouth to mouth resuscitation } \\
\text { to someone who had overdosed }\end{array}$ & 11.5 & 7.4 & 24.6 & 23.8 & 63.9 & 68.9 & 0.0143 \\
\hline $\begin{array}{l}\text { I would be able to perform chest compressions to } \\
\text { someone who had overdosed }\end{array}$ & 3.3 & 0 & 6.6 & 2.5 & 90.2 & 97.5 & 0.0027 \\
\hline $\begin{array}{l}\text { If someone overdoses, I would know what to do to help } \\
\text { them }^{\text {b }}\end{array}$ & 40.5 & 1.7 & 31.4 & 3.3 & 28.1 & 95 & $<.001$ \\
\hline $\begin{array}{l}\text { I would be able to place someone who had overdosed in } \\
\text { the recovery position }\end{array}$ & 31.2 & 0 & 33.6 & 0.8 & 35.3 & 99.2 & $<.001$ \\
\hline $\begin{array}{l}\text { I know very little about how to help someone who has } \\
\text { overdosed }^{\text {a }}\end{array}$ & 37.7 & 96 & 16.4 & 1.6 & 45.9 & 2.5 & $<.001$ \\
\hline \multirow[t]{2}{*}{ I would be able to deal effectively with an overdose ${ }^{b}$} & 32.8 & 0.8 & 45 & 8.2 & 22 & 91 & $<.001$ \\
\hline & \multicolumn{2}{|c|}{$\begin{array}{c}\text { Disagree/ } \\
\text { Completely } \\
\text { Disagree }\end{array}$} & \multicolumn{2}{|c|}{ Unsure } & \multicolumn{2}{|c|}{$\begin{array}{c}\text { Agree/ } \\
\text { Completely } \\
\text { Agree } \\
\end{array}$} & \\
\hline CONCERN Questions & $\begin{array}{c}\text { Pre } \\
\%\end{array}$ & $\begin{array}{c}\text { Post } \\
\%\end{array}$ & $\begin{array}{c}\text { Pre } \\
\%\end{array}$ & $\begin{array}{c}\text { Post } \\
\%\end{array}$ & $\begin{array}{c}\text { Pre } \\
\%\end{array}$ & $\begin{array}{c}\text { Post } \\
\%\end{array}$ & $P$ value \\
\hline $\begin{array}{l}\text { I would be afraid of giving naloxone in case the person } \\
\text { becomes aggressive afterwards }\end{array}$ & 50 & 65 & 26 & 9.7 & 23.5 & 25 & $<.001$ \\
\hline $\begin{array}{l}\text { I would be afraid of doing something wrong in an } \\
\text { overdose situation }^{\text {a }}\end{array}$ & 28.7 & 57.4 & 16.4 & 17 & 54.9 & 25 & $<.001$ \\
\hline $\begin{array}{l}\text { I would be reluctant to use naloxone for fear of } \\
\text { precipitating withdrawal symptoms }\end{array}$ & 65 & 87 & 25 & 9 & 9.8 & 4 & $<.001$ \\
\hline $\begin{array}{l}\text { I would be concerned about calling emergency services } \\
\text { in case the police come around }\end{array}$ & 89.4 & 90.2 & 4 & 1.6 & 6.5 & 8.1 & 0.3173 \\
\hline $\begin{array}{l}\text { If I tried to help someone who had overdosed, I might } \\
\text { accidentally hurt them }^{\text {a }}\end{array}$ & 46.3 & 75.2 & 36.3 & 14 & 17.36 & 10.7 & $<.001$ \\
\hline $\begin{array}{l}\text { I would be afraid of suffering a needle stick injury if I had } \\
\text { to give someone a naloxone injection }\end{array}$ & 74 & 84.5 & 11.4 & 6.5 & 14.6 & 9 & 0.0003 \\
\hline $\begin{array}{l}\text { I would prefer not to help someone who has overdosed, } \\
\text { because I'd feel responsible if they died }\end{array}$ & 94.3 & 86 & 5.7 & 9.8 & 0 & 4.1 & 0.0016 \\
\hline $\begin{array}{l}\text { Needles frighten me and I wouldn't be able to give } \\
\text { someone an injection of naloxone }{ }^{\mathrm{a}}\end{array}$ & 96.7 & 95.9 & 3.3 & 1.7 & 0 & 2.5 & 0.3173 \\
\hline
\end{tabular}




\section{American Journal of Pharmaceutical Education 2019; 83 (7) Article 6988.}

Table 5. (Continued)

\begin{tabular}{|c|c|c|c|c|c|c|c|}
\hline \multirow[b]{2}{*}{ READINESS Questions } & \multicolumn{2}{|c|}{$\begin{array}{c}\text { Disagree/ } \\
\text { Completely } \\
\text { Disagree }\end{array}$} & \multicolumn{2}{|c|}{ Unsure } & \multicolumn{2}{|c|}{$\begin{array}{c}\text { Agree/ } \\
\text { Completely } \\
\text { Agree }\end{array}$} & \multirow[b]{2}{*}{$P$ value } \\
\hline & $\begin{array}{l}\text { Pre } \\
\%\end{array}$ & $\begin{array}{c}\text { Post } \\
\%\end{array}$ & $\begin{array}{c}\text { Pre } \\
\%\end{array}$ & $\begin{array}{c}\text { Post } \\
\%\end{array}$ & $\begin{array}{c}\text { Pre } \\
\%\end{array}$ & $\begin{array}{c}\text { Post } \\
\%\end{array}$ & \\
\hline If someone overdoses, I want to be able to help them ${ }^{b}$ & 1.6 & 0 & 4.1 & 0 & 94.3 & 100 & - \\
\hline $\begin{array}{l}\text { Everyone at risk of witnessing an overdose should be } \\
\text { given a naloxone supply }{ }^{\mathrm{b}}\end{array}$ & 12.3 & 2.5 & 17.2 & 8.2 & 70.5 & 89.3 & $<.001$ \\
\hline $\begin{array}{l}\text { I couldn't just watch someone overdose, I would have to } \\
\text { do something to help }\end{array}$ & 0 & 0.8 & 3.3 & 0 & 96.8 & 99.2 & .0833 \\
\hline $\begin{array}{l}\text { If someone overdoses, I would call an ambulance but I } \\
\text { wouldn't be willing to do anything else } \mathrm{a}^{\mathrm{a}}\end{array}$ & 88.6 & 92.7 & 8.1 & 3.3 & 3.3 & 4.1 & .0253 \\
\hline $\begin{array}{l}\text { Family and friends of drug users should be prepared to } \\
\text { deal with an overdose }\end{array}$ & 0.8 & 0 & 1.6 & 0.8 & 97.6 & 99.2 & .1537 \\
\hline $\begin{array}{l}\text { If I witnessed an overdose, I would call an ambulance } \\
\text { straight away }^{\mathrm{a}}\end{array}$ & 94 & 13 & 4 & 42 & 1.6 & 45 & $<.001$ \\
\hline $\begin{array}{l}\text { If I saw an overdose, I would panic and not be able to } \\
\text { help }^{\mathrm{a}}\end{array}$ & 72.4 & 86 & 26.6 & 9.8 & 0 & 4 & $<.001$ \\
\hline I would stay with the overdose victim until help arrives ${ }^{b}$ & 0 & 0 & 0.8 & 0.8 & 99.2 & 99.2 & - \\
\hline $\begin{array}{l}\text { If I saw an overdose, I would feel nervous, but I would } \\
\text { still take the necessary actions }{ }^{\text {b }}\end{array}$ & 5 & 3.3 & 5 & 2.5 & 90 & 99 & .0253 \\
\hline $\begin{array}{l}\text { I will do whatever is necessary to save someone's life in } \\
\text { an overdose situation }\end{array}$ & 0.8 & 0 & 5.7 & 3.3 & 93.4 & 96.7 & .0455 \\
\hline
\end{tabular}

${ }^{a}$ McNemar's test was performed between pre- and post-test (disagree/completely disagree) category only

${ }^{\mathrm{b}} \mathrm{McNemar}$ 's test was performed between pre- and post-test (agree/completely agree) category only

opioid overdose, the symptoms associated with opioid withdrawal, and naloxone's reversal role in reversing the physiological effects of an opioid overdose. Based on students' initial attitudes and knowledge-based assessments, areas for improvement were related to student's confidence in integrating these concepts into practice. These areas included identifying medication schedules in the Virginia PDMP and distinguishing between different naloxone devices and their technical administration considerations. Upon completion of the opioid laboratory session, the students possessed a greater degree of confidence to independently manage a patient experiencing an opioid overdose.

The investigators recognize many opportunities for improving the laboratory session. Because the mock patient counseling activity gave the students an opportunity to use the atomizer device, this significantly increased students' confidence level in handling this product. The decrease in confidence level observed with using naloxone auto-injectors and poor performance on the knowledge assessment highlight the limitations of teaching students solely by giving an in-class demonstration of how to use a device and having only half of the students use the device in the REVIVE! certification process. This emphasizes the need for a hands-on learning activity with all students having the opportunity to use all of the naloxone devices. Additionally, about $50 \%$ of students consistently missed a question pertaining to schedules of medications included in the PDMP. This highlights the need for educators to stress this distinction

Table 6. Pharmacy Students' Scores on Question Categories on the Opioid Overdose Attitude Scale (OOAS) ${ }^{\text {a }}$ Before and After Completing an Opioid Overdose Management Laboratory Session $(\mathrm{N}=129)^{11,12}$

\begin{tabular}{lccr}
\hline OOAS Scores & Pretest Score (Median) & Posttest Score (Median) & $\boldsymbol{p}$ Value \\
\hline Competence & 28 & 43 & $<.001$ \\
Concerns & 30 & 32 & $<.001$ \\
Readiness & 32 & 34 & $<.001$ \\
Total OOAS & 89 & 109 & $<.001$ \\
\hline
\end{tabular}

a The total possible score on the OOAS ranged from 28 to 140 points 


\section{American Journal of Pharmaceutical Education 2019; 83 (7) Article 6988.}

in the PDMP discussion portion. Accurate dosing conversion and interpretation are core responsibilities for a pharmacist and are skills essential to preventing unintended adverse drug reactions and overdose. Although $100 \%$ of students correctly performed an equianalgesic conversion on their examination, only $75 \%$ reported they were confident in their abilities to do so in a patient care setting, despite the practice they received in the laboratory activity. This identifies the need for additional focused activities to train the remaining quarter.

Other factors may have influenced the difference in respondents' confidence levels. Students who expressed uncertainty about their aptitude for this subject may not have anticipated the multifactorial aspects of prompt opioid overdose recognition and management, the variety of naloxone devices and unique administration considerations associated with each form, and regulation and monitoring responsibilities involved to prevent future overdoses. Furthermore, the knowledge gap and effort to improve the students' confidence level regarding this topic emphasize the importance of conducting other active-learning sessions, such as experiential practice during rotations and internships. With additional mentored training, students will be able to strengthen their clinical application skills and improve their selfconfidence.

This laboratory could be implemented in other schools of pharmacy. Narcan nasal spray and EVZIO auto-injector were provided for student training by the manufacturers at no cost to the university. The naloxone nasal atomizers and REVIVE! training materials (gloves, face shields, naloxone stickers) were provided at no cost from the Virginia Department of Behavioral Health and Developmental Services. The lecture and PDMP discussion were each led by one faculty member, but several evaluators were needed for the student naloxone counseling and certification. Having sufficient manpower was the biggest challenge to implementing the hands-on portion of this laboratory. Using fourth-year PharmD students and residents may help in overcoming this barrier. The coordinators plan to continue this activity in the skills laboratory course. Modifications to the counseling and/or REVIVE! certification portions of the laboratory training session may be made as doing both at the same time requires at least eight to nine facilitators per laboratory session.

\section{CONCLUSION}

An active-learning laboratory on the management of opioid overdose improved pharmacy students' knowledge, confidence, and attitudes in several of the areas assessed. Additional hands-on practice with all of the naloxone devices, especially the auto-injector, in the classroom may be beneficial. The opioid epidemic and the pharmacists' role in addressing it can be incorporated into the PharmD curriculum in several ways. An activelearning laboratory is one way to ensure pharmacy students acquire the training they need to be better prepared to face this crisis.

\section{REFERENCES}

1. Fleming ML, Barner JC, Brown CM, et al. Pharmacists' training, perceived roles, and actions associated with dispensing controlled substance prescriptions. JAPhA. 2014;54:241-250.

2. Understanding the Epidemic. Centers for Disease Control and Prevention. https://www.cdc.gov/drugoverdose/epidemic/ index.html. Published December 16, 2016. Accessed June 20, 2018. 3. Porter J, Jick H. Addiction rare in patients treated with narcotics. $N$ Engl J Med. 1980;302:123.

4. Rummans TA, Burton MC, Dawson NL. How good intentions contributed to bad outcomes: the opioid crisis. Mayo Clinic Proceedings. 2017;93(3):344-350.

5. ASHP Statement on the Pharmacist's Role in Substance Abuse Prevention, Education, And Assistance. AJHP. 2014;71:243-246. 6. Association AP. Pharmacists' role in addressing opioid abuse, addiction, and diversion. JAPhA. 2013;5:5-15.

7. Muzyk AJ, Peedin E, Lipetzky J, et al. Substance use education in US schools of pharmacy: a systematic review of the literature. Substance Abuse. 2017;1-9.

8. AACP Final Report of the 2016-17 Bylaws and Policy Development Committee. http://www.aacp.org/advocacy/ WhatDoesAACPAdvocateFor/BudgetandAppropriations/ Documents/BPDC\%20Report $\% 20$ for $\% 20$ the $\% 20$ Final $\% 20$ House $\%$ 20of\%20Delegates\%20FINAL\%2020170807.pdf. Published July 19, 2017. Accessed August 13, 2017.

9. REVIVE! Opioid Overdose and Naloxone Education for Virginia. http://dbhds.virginia.gov/developmental-services/substance-abuseservices/revive. Accessed June 20, 2018.

10. Opioid overdose prevention programs providing naloxone to laypersons - United States, 2014. Morbidity and Mortality Weekly Report (MMWR). 2015;64(23):631-635. https://www.cdc.gov/ mmwr/preview/mmwrhtml/mm6423a2.htm. Accessed April 3, 2018. 11. Opioid Overdose Attitudes Scale. https://www.kcl.ac.uk/ioppn/ depts/addictions/research/drugs/Naloxone/Opioid-OverdoseAttitudes-Scale.pdf. Accessed January 31, 2018.

12. Opioid Overdose Attitude Scale Scoring Instructions. https:// www.kcl.ac.uk/ioppn/depts/addictions/research/drugs/Naloxone/ OOAS-Instructions.pdf. Accessed June 20, 2018. 